\title{
Prevalence and Determinants of Anemia among Adolescent Girls: A School-Based Survey in Central Java, Indonesia
}

\author{
Siti Masfiah ${ }^{1}$, Arrum Firda Ayu Maqfiroch ${ }^{1}$, Windri Lesmana Rubai ${ }^{1}$, Siwi Pramatama Mars WIjayanti ${ }^{1}$, \\ Dian Anandari ${ }^{1}$, Arif Kurniawan ${ }^{1}$, Saryono ${ }^{1} \&$ Budi Aji $^{1}$ \\ ${ }^{1}$ Faculty of Health Sciences, Jenderal Soedirman University, Indonesia \\ Correspondence: Siti Masfiah, Faculty of Health Sciences, Jenderal Soedirman University, Indonesia
}

Received: December 7, 2020 Accepted: February 4, 2021 Online Published: February 15, 2021

doi:10.5539/gjhs.v13n3p37 URL: https://doi.org/10.5539/gjhs.v13n3p37

\begin{abstract}
Introduction: Anemia is the most common and inflexible nutritional problem affecting about 2 billion of the world's population with a significant impact on human health and social and economic development. Information about anemia prevalence and associated factors among adolescent girls in Indonesia is still limited.
\end{abstract}

Objective: This study aimed to examine determinant factors related to anemia among adolescent girls.

Methode: This is an analytic study with a cross-sectional design, located in three regencies in Central Java Indonesia. This is a school-based survey in several senior high schools in three regencies that have a higher number of stunting cases, as a related indicator of Anemia. A total of 388 adolescent girls have participated in this study. Anemic status was assessed using HB quick-check. Independent variables such as breakfast habit, father's height, allowance per day, etc. were collected by a structured questionnaire. Data analysis is carried out by univariate, bivariate, and multivariate. Ethical clearance has been approved by Medicine Faculty Ethics Committee, Jenderal Soedirman University.

Result: The study found that $26,3 \%$ of girls were categorized as having anemia. Results showed that there was a correlation between anemic and breakfast habit $(\mathrm{p}=0.07)$, and allowance per day $(\mathrm{p}=0.08)$, and father's height ( $\mathrm{p}$ $=0.01$ ) among adolescent girls.

Conclusion: This research highlighted the importance for the adolescent girl of having daily breakfast. Good eating habits can help to reduce the incidence of anemia and its negative adverse health effects.

Keywords: anemia, adolescent, girl, Indonesia

\section{Introduction}

Globally, anemia is the most common and inflexible nutritional problem affecting about 2 billion of the world's population with a significant impact on human health and social and economic development. Anemia is characterized as a condition in which the number and oxygen-carrying ability of red blood cells (RBCs) is inadequate to meet the physiological needs of the body (Castro De Andrade Cairo et al., 2014; Soundarya \& Suganthi, 2016). Iron deficiency anemia is the most common cause of anemia, accounting for half of all cases (Christian \& Smith, 2018). Iron deficiency anemia can occur at all stages of life and is more common among pregnant women, young children, and adolescents. Adolescent particularly girl is the one of the vulnerable group at risk of anemia. This because of the increase of nutrient requirements during this period due to rapid changes in their physical dimension and body composition. Since this time is often ignored, adolescent girls are subjected to various forms of macro-and micronutrient malnutrition and therefore the period is the last opportunity to break the vicious cycle of intergenerational connection (Ramzi et al., 2011). Also, the adolescent girl also more vulnerable to experience social discrimination and pressure such as detailing with body image (Christian \& Smith, 2018).

The drawbacks associated with iron deficiency anemia include lower academic potential; lower well-being and performance at home or in the community; and increased maternal and child morbidity and mortality for pregnant adolescents (WHO, 2011). The previous study also showed that stunting in children is also associated with the condition of mothers who have anemia (Rahman, Mushfiquee, Masud, \& Howlader, 2019). Indonesia is the fourth-highest average stunting prevalence in Southeast Asia in 2005-2017 (36\%) after Laos (44\%), Bangladesh (42\%), and Cambodia (40\%). Based on the 2018 Basic Health Research Survey, stunting events in children across the country reached $30.8 \%(\mathrm{IMoH}, 2019)$. The prevention of anemia in adolescent girls is one of the attempts made 
to reduce the incidence of stunting. However, anemia often becomes a neglected issue that did not receive much attention.

Indeed, identifying factors associated with anemia in adolescent girls is undoubtedly important for diminish the health problem related to anemia. A previous study showed that dietary diversity score, household security status, and living status were associated with anemia incidence of adolescent girls (Gonete, Tariku, Wami, \& Derso, 2018). Heme iron food consumption also showed a significant association with anemia, where adolescent girls who consumed heme iron foods less than once a month were 11 times more likely to develop anemia compared to those who eat more than twice a week (Engidaw, Wassie, \& Teferra, 2018). Information about the prevalence of anemia and associated factors among adolescent girls in Indonesia is still limited. In the current study, we eager to determine the prevalence of anemia among adolescent girls based on a school-based survey. Besides, we also analyze the associated factors with anemia. The results of this study would provide crucial information for implementing a successful intervention to enhance their nutritional status to avoid the incidence of various risks during puberty, pregnancy, childbirth, and beyond.

\section{Method}

\subsection{Study Location and Design}

This is an analytical study with a cross-sectional design. This research is located in three regencies in Central Java namely Banyumas, Purbalingga, and Kebumen districts from June-September 2019. This research was conducted at selected senior high schools in the three districts. The districts were chosen based on their high number of stunting cases. Since there was no data on anemia in adolescents, stunting which was a related indicator of anemia was used. Stunting cases in Indonesia highly occurred in the child from young mothers, thus the government started to concern about the maternal health of adolescents.

\subsection{Sampling Method}

The population of this study was senior high school girls students aged 16-18 in Central Java. This study involved 388 adolescent girls from 12 senior high schools. Class 12 was chosen since most of the age group criteria were there. It also related to administrative reason, which just allowed researchers to approached class 12, since class 11 and 13 were in the tight academic schedules. The population involved in this study was all the high schools in 3 selected districts, which include public schools, private schools, vocational schools, and Islamic schools. Systematic random sampling was applied to select the sample.

\subsection{Data Collection}

The dependent variable of this study was anemic status which was assessed using Haemoglobin measurement taken by Hb-quick check using Easy-touch GCHP test-kit. Independent variables such as allowance per day, parental education, parental income, number of family members, availability of latrines at home, breakfast habit, menstruation period, parents height, nutritional status (BMI indicator), history of infectious disease, intake sources of iron and zinc were carried out by structured questionnaire. The height of the father and mother was assessed based on the self-report of the respondent. Breakfast habit was measured as a behavior aspect. It was asked using a range frequent scale. The question is how frequent do you have breakfast. The answer options are every day, often, seldom, never. There was no assessment of the nutritional content of breakfast.

\subsection{Data Analysis}

Data analysis is carried out by univariate, bivariate, and multivariate. Logistic regression was applied to investigate the determinant factors related to anemia. Results of this study represented in tables.

\subsection{Ethics Consideration}

Ethical clearance for this research has been approved by Medicine Faculty Ethics Committee, Jenderal Soedirman University No. 346/KEPK/X/2019.

\section{Result}

A total of 388 young women students were cited in this study. They were interviewed about several variables examined in this study. $73,7 \%$ of respondents did not have anemia, while $26,3 \%$ were categorized as having anemia. Details of respondent's characteristics can be seen in Table 1. 
Table 1. Anemic Status and Demographic characteristics of respondents

\begin{tabular}{|c|c|c|}
\hline Characteristics & Number & Percentage \\
\hline \multicolumn{3}{|l|}{ Anemia } \\
\hline Yes & 102 & 26,3 \\
\hline No & 286 & 73,7 \\
\hline \multicolumn{3}{|l|}{ Father's education } \\
\hline Didn't finish elementary school & 11 & 2,8 \\
\hline Elementary school & 186 & 47,9 \\
\hline Junior Highs School & 60 & 15,5 \\
\hline Senior High School & 91 & 23,5 \\
\hline Higher education (university) & 40 & 10,3 \\
\hline \multicolumn{3}{|l|}{ Mother's education } \\
\hline Didn't finish elementary school & 9 & 2,3 \\
\hline Elementary school & 200 & 51,5 \\
\hline Junior High School & 79 & 20,4 \\
\hline Senior High School & 74 & 19,1 \\
\hline Higher education (University) & 26 & 6,7 \\
\hline \multicolumn{3}{|l|}{ Parents income } \\
\hline High & 130 & 34,2 \\
\hline Low & 250 & 65,8 \\
\hline \multicolumn{3}{|l|}{ Father's occupation } \\
\hline Unemployment & 9 & 2,4 \\
\hline Student & 1 & 0,3 \\
\hline Civil servant & 19 & 5,0 \\
\hline Private Employee & 34 & 8,9 \\
\hline Entrepreneur & 88 & 23,0 \\
\hline Others & 231 & 60,5 \\
\hline \multicolumn{3}{|l|}{ Mother's occupation } \\
\hline Unemployment & 218 & 56,6 \\
\hline Student & 1 & 0,3 \\
\hline Civil servant & 11 & 2,9 \\
\hline Private Employee & 15 & 3,9 \\
\hline Entrepreneur & 29 & 7,5 \\
\hline others & 111 & 28,8 \\
\hline \multicolumn{3}{|l|}{ Number of a family member } \\
\hline$\leq 4$ people & 208 & 54,6 \\
\hline$>4$ people & 173 & 45,4 \\
\hline \multicolumn{3}{|l|}{ Age differences with siblings } \\
\hline$\geq 3$ years or the only child & 291 & 76,4 \\
\hline$<3$ years & 90 & 23,6 \\
\hline \multicolumn{3}{|l|}{ Water source } \\
\hline Local water company & 81 & 20,9 \\
\hline
\end{tabular}




\begin{tabular}{lll}
\hline Well & 261 & 67,4 \\
Others & 45 & 11,6 \\
\hline The existences of a latrine & 363 & 93,8 \\
Yes & 24 & 6,2 \\
No & & \\
\hline Breakfast habits & 27 & 7,0 \\
Never & 36 & 9,3 \\
Rarely & 26 & 6,7 \\
Often & 298 & 77,0 \\
Always & & \\
\hline Nutritional status & 91 & 23,5 \\
Underweight & 255 & 65,7 \\
Normal & 21 & 5,4 \\
Overweight & 21 & 5,4 \\
Obese & &
\end{tabular}

\section{History of infectious disease}

Yes

No

\section{Consumption of animal protein}

Less than recommendation $386 \quad 99,5$

Appropriate to recommendation

2

0,5

\section{Consumption of plant protein}

Less than recommendation

There were several interesting facts based on Table 1 . Only $0.3 \%$ of respondents consumed vegetable protein which according to recommendations, while majority of respondents $(99.7 \%)$ were still less than recommendation. While based on the results of the bivariate analysis, it was found that the variable that had an effect on the incidence of anemia was breakfast habit $(p=0.07)$. Meanwhile, father's education $(p=0,523)$, mother's education $(p=0,845)$, parents' income ( $p=0,752)$, father's occupation $(p=0,806)$, mother's occupation $(p=0,833)$, number of family members living in the same household $(p=0.309)$, age difference with siblings $(p=0.143)$, water source $(p=0.213)$, latrines $(p=0.176)$, nutritional status $(p=0.828)$, history of infectious disease $(0.989)$, protein consumption animal $(p=1)$ and consumption of vegetable protein $(p=1)$ are not related to the incidence of anemia (Supplementary data 2)

The mean difference test results showed that variables related to anemia were per day allowance $(p=0.040)$ and father's height $(p=0.016)$. Meanwhile, the number of menstrual days $(p=0.561)$ and maternal height $(p=0.584)$ were not related to the incidence of anemia. Based on the results of the bivariate analysis, it was found that the variables included as multivariate test candidates $(\mathrm{p} \leq 0.25)$ were differences in age with siblings, breakfast habits, amount of allowance per day, and father's height (Supplementary data 3). The multivariate analysis can be seen in Table 2. 
Table 2. Multivariate analysis

\begin{tabular}{llll}
\hline Variables & $\boldsymbol{p}$ & OR & $\mathbf{9 5 \%}$ C.I \\
\hline Water source & & & \\
Well & 0,139 & 0,65 & $0,37-1,15$ \\
Others & 0,146 & 0,50 & $0,20-1,27$ \\
\hline The existence of a latrine & 0,184 & 0,42 & $012-1,51$ \\
\hline Breakfast habits (every day) & & & \\
Never & 0,088 & 2,10 & $0,90-4,92$ \\
Rarely & 0,111 & 0,44 & $0,16-1,20$ \\
Often & 0,755 & 1,15 & $0,47-2,82$ \\
\hline Allowance per day & 0,083 & 1,00 & $1,00-1,00$ \\
\hline Father's height & 0,012 & 1,05 & $1,01-1,09$ \\
\hline
\end{tabular}

The results of logistic regression showed that the variable most influential on the incidence of anemia was the father's height where adolescents who had higher fathers had a 1.05 times risk of developing anemia compared to shorter fathers. It needs to be studied more, whether if father's height is higher than average are more likely to have calorie intake history in his diet or not. Water source, the existence of latrine, breakfast habit, and allowance per day did not influence together on anemic status. The allowance per day used in the analysis was a continuous variable, with the minimum allowance per day of female high school students was 2,000 rupiah and the maximum was 100,000 rupiah.

\section{Discussion}

In this study, we found that the variable that affected the incidence of anemia was breakfast habit, per day allowance and father's height. These results supporting the previous research which stated that a balanced diet and daily breakfast is one effort to improve nutritional quality in addressing the lack of protein and fuel nutritional anemia. Breakfast habit before 9 a.m can provide 15-30 percent of daily nutrition needs as part of a balanced diet for healthy living (Abalkhail \& Shawky, 2002). Skipping breakfast can cause morning nutrient deficiency in the body and increase the risk of malnutrition. This also can lead to excessive consumption of food in other meals, especially dinner, thus causing obesity (Jawed, Tariq, Tariq, \& Kamal, 2017). Adolescents who eat breakfast regularly also has better academic performance and competences (MacLellan, Taylor, \& Wood, 2008). Besides, adolescent girls have a relatively higher intake of micronutrients, whereas those who do not eat breakfast may have vitamin A, vitamin B6, calcium, copper, iron, magnesium, and zinc deficiencies (Hwalla et al., 2017).

Skipping breakfast could lead the deficiencies of nutrients and the development of anemia. The mechanism of developing anemia iron deficiency is divided into three stages, i.e. the first step is a decrease in iron reserves in the liver expressed in serum or ferritin plasma levels, the second phase of further decline in iron deposits before saturation loss is reduced. The third phase entails a lack of iron deposits to minimize circulation iron levels and the development of microcytic hypochromic anemia resulting in reduced hemoglobin concentrations in red blood cells (Joosten, 2018).

Other variable found associated with anemia is the allowance per day. This is likely because the amount of allowance will impact young women's ability to purchase other food to meet their nutritional needs. These facts following the previous finding stated that that socioeconomic status (SES) and anemia are certainly linked. The percentage of anemia among adolescent girls was higher in the lower socio-economic strata (Kim et al., 2014). Also, the results of multivariate analysis showed that the variable most influential on the incidence of anemia was the father's height where adolescents who had higher fathers had a 1.1 times risk of developing anemia compared to shorter fathers. This finding is a new fact found in this report, as it is rarely mentioned so far. A previous study showed the association between maternal height and child mortality, anthropometric failure, and anemia (Subramanian, Ackerson, Smith, \& John, 2009). Maternal height can be a useful marker for characterizing intergenerational health linkages because adult height represents the health inventory of a mother accrued over her life course, particularly in her early childhood social and environmental exposures. These results require further and in-depth study to find out why a father's height can be related to anemia in his daughter. 
In this study, there were several variables such as nutritional status, history of infectious disease, and protein consumption not related to anemia. This is not following previous research that mentioned the correlation of several of these variables with the incidence of anemia (Teji, Dessie, Assebe, \& Abdo, 2016). Nutritional status in adolescent girls is often affected by eating behavior and body image and could be caused anemia. Malnutrition in adolescents results in limitations on food consumption by not paying attention to nutrition and health laws, so the quantity and quality of nutritional intake are not consistent with the prescribed Diet Adequacy Level. These limits on food consumption harm the nutritional status of adolescents (Regasa \& Haidar, 2019). This research highlights the importance for adolescent girls of daily breakfast so that they can fulfill their nutritional needs and avoid anemia. Good eating habits can help to reduce the incidence of anemia and its negative adverse health effects.

\section{Acknowledgments}

We thank the Department of Health Promotion, Ministry of Health for the grant to this program (Grant number: KN.01.02/I/4232/2019).

\section{Competing Interests Statement}

The authors declare that there are no competing or potential conflicts of interest.

\section{References}

Abalkhail, B., \& Shawky, S. (2002). Prevalence of daily breakfast intake, iron deficiency anemia and awareness of being anaemic among Saudi school students. International Journal of Food Sciences and Nutrition, 53(6), 519-528. https://doi.org/10.1080/09637480220164370

Castro De Andrade Cairo, R., Rodrigues Silva, L., Bustani, N. C., Dantas, C., \& Marques, F. (2014). Iron deficiency anemia in adolescents; a literature review. Nutr Hosp, 29(6), 1240-1249. https://doi.org/10.3305/nh.2014.29.6.7245

Christian, P., \& Smith, E. R. (2018). Adolescent Undernutrition: Global Burden, Physiology, and Nutritional Risks. Annals of Nutrition and Metabolism, 72(4), 316-328. https://doi.org/10.1159/000488865

Engidaw, M. T., Wassie, M. M., \& Teferra, A. S. (2018). Anemia and associated factors among adolescent girls living in Aw-Barre refugee camp, Somali regional state, Southeast Ethiopia. PLOS ONE, 13(10), e0205381. https://doi.org/10.1371/journal.pone.0205381

Gonete, K. A., Tariku, A., Wami, S. D., \& Derso, T. (2018). Prevalence and associated factors of anemia among adolescent girls attending high schools in Dembia District, Northwest Ethiopia, 2017. Archives of Public Health, 76(1). https://doi.org/10.1186/s13690-018-0324-y

Hwalla, N., Al Dhaheri, A. S., Radwan, H., Alfawaz, H. A., Fouda, M. A., Al-Daghri, N. M., ... Blumberg, J. B. (2017, March 3). The prevalence of micronutrient deficiencies and inadequacies in the middle east and approaches to interventions. Nutrients. MDPI AG. https://doi.org/10.3390/nu9030229

IMoH. (2019). Indonesia National Basic Health Survey. Jakarta. https://doi.org/10.1177/109019817400200403

Jawed, S., Tariq, S., Tariq, S., \& Kamal, A. (2017). Frequency of nutritional anemia among female medical students of Faisalabad. Pakistan Journal of Medical Sciences, 33(2), 398-403. https://doi.org/10.12669/pjms.332.11854

Joosten, E. (2018). Iron deficiency anemia in older adults: A review. Geriatrics and Gerontology International, 18(3), 373-379. https://doi.org/10.1111/ggi.13194

Kim, J. Y., Shin, S., Han, K., Lee, K. C., Kim, J. H., Choi, Y. S., .. Ko, B. J. (2014). Relationship between socioeconomic status and anemia prevalence in adolescent girls based on the fourth and fifth Korea National Health and Nutrition Examination Surveys. European Journal of Clinical Nutrition, 68(2), 253-258. https://doi.org/10.1038/ejen.2013.241

MacLellan, D., Taylor, J., \& Wood, K. (2008). Food intake and academic performance among adolescents. Canadian Journal of Dietetic Practice and Research, 69(3), 141-144. https://doi.org/10.3148/69.3.2008.141

Rahman, M. S., Mushfiquee, M., Masud, M. S., \& Howlader, T. (2019). Association between malnutrition and anemia in under-five children and women of reproductive age: Evidence from Bangladesh demographic and Health Survey 2011. PLoS ONE, 14(7). https://doi.org/10.1371/journal.pone.0219170

Ramzi, M., Haghpanah, S., Malekmakan, L., Cohan, N., Baseri, A., Alamdari, A., \& Zare, N. (2011). Anemia and iron deficiency in adolescent school girls in Kavar Urban area, Southern Iran. Iranian Red Crescent Medical Journal, 13(2), 128-133. Retrieved from /pmc/articles/PMC3371916/?report=abstract 
https://doi.org/10.1111/j.0958-7578.2005.00590.x

Regasa, R. T., \& Haidar, J. A. (2019). Anemia and its determinant of in-school adolescent girls from rural Ethiopia: A school based cross-sectional study. BMC Women's Health, 19(1), 1-7. https://doi.org/10.1186/s12905-019-0791-5

Soundarya, N., \& Suganthi, P. (2016). A Review on Anaemia-Types, Causes, Symptoms and Their Treatments. Journal of Science and Technology Investigation, 1(1), 10-17. Retrieved from https://www.researchgate.net/publication/324247750_A_review_on_anaemia_-_types_causes_symptoms_a nd their_treatments

Subramanian, S. V., Ackerson, L. K., Smith, G. D., \& John, N. A. (2009). Association of maternal height with child mortality, anthropometric failure, and anemia in India. JAMA - Journal of the American Medical Association, 301(16), 1691-1701. https://doi.org/10.1001/jama.2009.548

Teji, K., Dessie, Y., Assebe, T., \& Abdo, M. (2016). Anaemia and nutritional status of adolescent girls in Babile District, Eastern Ethiopia. Pan African Medical Journal, 24. https://doi.org/10.11604/pamj.2016.24.62.6949

WHO. (2011). Intermittent iron and folic acid supplementation in menstruating women ii Intermittent iron and folic acid supplementation in menstruating women Suggested citation WHO Library Cataloguing-in-Publication Data. Geneva: WHO. Retrieved from http://www.who.int/about/licensing/copyright_form/en/index.html

Abalkhail, B., \& Shawky, S. (2002). Prevalence of daily breakfast intake, iron deficiency anemia and awareness of being anaemic among Saudi school students. International Journal of Food Sciences and Nutrition, 53(6), 519-528. https://doi.org/10.1080/09637480220164370

Castro De Andrade Cairo, R., Rodrigues Silva, L., Bustani, N. C., Dantas, C., \& Marques, F. (2014). Iron deficiency anemia in adolescents; a literature review. Nutr Hosp, 29(6), 1240-1249. https://doi.org/10.3305/nh.2014.29.6.7245

Christian, P., \& Smith, E. R. (2018). Adolescent Undernutrition: Global Burden, Physiology, and Nutritional Risks. Annals of Nutrition and Metabolism, 72(4), 316-328. https://doi.org/10.1159/000488865

Engidaw, M. T., Wassie, M. M., \& Teferra, A. S. (2018). Anemia and associated factors among adolescent girls living in Aw-Barre refugee camp, Somali regional state, Southeast Ethiopia. PLOS ONE, 13(10), e0205381. https://doi.org/10.1371/journal.pone.0205381

Gonete, K. A., Tariku, A., Wami, S. D., \& Derso, T. (2018). Prevalence and associated factors of anemia among adolescent girls attending high schools in Dembia District, Northwest Ethiopia, 2017. Archives of Public Health, 76(1). https://doi.org/10.1186/s13690-018-0324-y

Hwalla, N., Al Dhaheri, A. S., Radwan, H., Alfawaz, H. A., Fouda, M. A., Al-Daghri, N. M., ... Blumberg, J. B. (2017, March 3). The prevalence of micronutrient deficiencies and inadequacies in the middle east and approaches to interventions. Nutrients. MDPI AG. https://doi.org/10.3390/nu9030229

IMoH. (2019). Indonesia National Basic Health Survey. Jakarta. https://doi.org/10.1177/109019817400200403

Jawed, S., Tariq, S., Tariq, S., \& Kamal, A. (2017). Frequency of nutritional anemia among female medical students of Faisalabad. Pakistan Journal of Medical Sciences, 33(2), 398-403. https://doi.org/10.12669/pjms.332.11854

Joosten, E. (2018). Iron deficiency anemia in older adults: A review. Geriatrics and Gerontology International, 18(3), 373-379. https://doi.org/10.1111/ggi.13194

Kim, J. Y., Shin, S., Han, K., Lee, K. C., Kim, J. H., Choi, Y. S., ... Ko, B. J. (2014). Relationship between socioeconomic status and anemia prevalence in adolescent girls based on the fourth and fifth Korea National Health and Nutrition Examination Surveys. European Journal of Clinical Nutrition, 68(2), 253-258. https://doi.org/10.1038/ejen.2013.241

MacLellan, D., Taylor, J., \& Wood, K. (2008). Food intake and academic performance among adolescents. Canadian Journal of Dietetic Practice and Research, 69(3), 141-144. https://doi.org/10.3148/69.3.2008.141

Rahman, M. S., Mushfiquee, M., Masud, M. S., \& Howlader, T. (2019). Association between malnutrition and anemia in under-five children and women of reproductive age: Evidence from Bangladesh demographic and Health Survey 2011. PLoS ONE, 14(7). https://doi.org/10.1371/journal.pone.0219170

Ramzi, M., Haghpanah, S., Malekmakan, L., Cohan, N., Baseri, A., Alamdari, A., \& Zare, N. (2011). Anemia and 
iron deficiency in adolescent school girls in Kavar Urban area, Southern Iran. Iranian Red Crescent Medical Journal, 13(2), 128-133. https://doi.org/10.1111/j.0958-7578.2005.00590.x

Regasa, R. T., \& Haidar, J. A. (2019). Anemia and its determinant of in-school adolescent girls from rural Ethiopia: A school based cross-sectional study. BMC Women's Health, 19(1), 1-7. https://doi.org/10.1186/s12905-019-0791-5

Soundarya, N., \& Suganthi, P. (2016). A Review on Anaemia -Types, Causes, Symptoms and Their Treatments. Journal of Science and Technology Investigation, 1(1), 10-17. Retrieved from https://www.researchgate.net/publication/324247750_A_review_on_anaemia_-_types_causes_symptoms_a nd_their_treatments

Subramanian, S. V., Ackerson, L. K., Smith, G. D., \& John, N. A. (2009). Association of maternal height with child mortality, anthropometric failure, and anemia in India. JAMA - Journal of the American Medical Association, 301(16), 1691-1701. https://doi.org/10.1001/jama.2009.548

Teji, K., Dessie, Y., Assebe, T., \& Abdo, M. (2016). Anaemia and nutritional status of adolescent girls in Babile District, Eastern Ethiopia. Pan African Medical Journal, 24. https://doi.org/10.11604/pamj.2016.24.62.6949

WHO. (2011). Intermittent iron and folic acid supplementation in menstruating women ii Intermittent iron and folic acid supplementation in menstruating women Suggested citation WHO Library Cataloguing-in-Publication Data. Geneva: WHO. Retrieved from http://www.who.int/about/licensing/copyright_form/en/index.html 


\section{Appendix A}

Table A1. Univariate analysis results

\begin{tabular}{lcccc}
\hline \multicolumn{1}{c}{ Variabel } & n & Mean & SD & Min -Maks \\
\hline Allowance per day (IDR) & 387 & 10954,78 & 8809,1 & $2000-100.000$ \\
Menstruation periode (day) & 388 & 6,71 & 1,28 & $3-15$ \\
Father's height (cm) & 381 & 164,9 & 6,81 & $143-182$ \\
Mother's height (cm) & 381 & 153,85 & 6,34 & $133-190$ \\
\hline
\end{tabular}

Table A2. Bivariate analysis results

\begin{tabular}{|c|c|c|c|c|c|}
\hline \multirow{3}{*}{ Variabel } & \multicolumn{4}{|c|}{ Anemia } & \multirow{3}{*}{ p-value } \\
\hline & \multicolumn{2}{|c|}{ Yes } & \multicolumn{2}{|l|}{ No } & \\
\hline & $\mathbf{n}$ & $\%$ & $\mathbf{n}$ & $\%$ & \\
\hline \multicolumn{6}{|l|}{ Father's education } \\
\hline Didn't finish elementary school & 2 & 18,2 & 9 & 81,8 & \multirow{5}{*}{0,523} \\
\hline Elementary school & 43 & 23,1 & 143 & 76,9 & \\
\hline Junior Highs School & 19 & 31,7 & 41 & 68,3 & \\
\hline Senior High School & 28 & 30,8 & 63 & 69,2 & \\
\hline Higher education (university) & 10 & 25,0 & 30 & 75,0 & \\
\hline \multicolumn{6}{|l|}{ Mother's occupation } \\
\hline Unemployment & & & & & \multirow{6}{*}{0,845} \\
\hline Student & 2 & 22,2 & & & \\
\hline Civil servant & & $24, J$ & 101 & ני, & \\
\hline Private Employee & 24 & 30,4 & 53 & 09,0 & \\
\hline Enterpreneur & 21 & 28,4 & 53 & 71,6 & \\
\hline others & 6 & 23,1 & 20 & 76,9 & \\
\hline \multicolumn{6}{|l|}{ Parents income } \\
\hline$<$ District Minimum Wage (DMW) & 64 & 25,6 & 186 & 74,4 & \multirow{2}{*}{0,752} \\
\hline$\geq$ DMW (1.900.000 rupiah) & 36 & 27,7 & 94 & 72,3 & \\
\hline \multicolumn{6}{|l|}{ Father's occupation } \\
\hline Unemployment & 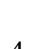 & & & & \multirow{6}{*}{0,806} \\
\hline Student & 7 & 44,4 & 3 & 3,0 & \\
\hline Civil servant & 0 & 0,0 & & 100,0 & \\
\hline Private Employee & 5 & 26,3 & 14 & 73,7 & \\
\hline Enterpreneur & 8 & 23,5 & 26 & 76,5 & \\
\hline Others & 24 & 27,3 & 64 & 72,7 & \\
\hline \multicolumn{6}{|l|}{ Mother's occupation } \\
\hline Unemployment & 58 & 26,6 & 160 & 73,4 & \multirow{6}{*}{0,833} \\
\hline Student & 0 & 0,0 & 1 & 100,0 & \\
\hline Civil servant & 3 & 27,3 & 8 & 72,7 & \\
\hline Private Employee & 4 & 26,7 & 11 & 73,3 & \\
\hline Enterpreneur & 5 & 17,2 & 24 & 81,8 & \\
\hline others & 31 & 27,9 & 72,1 & 72,1 & \\
\hline
\end{tabular}




\begin{tabular}{|c|c|c|c|c|c|}
\hline \multicolumn{6}{|l|}{ Number of a family member } \\
\hline$\leq 4$ people & 41 & 23,7 & 148 & 76,3 & \multirow{2}{*}{0,309} \\
\hline$>4$ people & 60 & 28,8 & 132 & 71,2 & \\
\hline \multicolumn{6}{|l|}{ Age differences with siblings } \\
\hline$\geq 3$ years or the only child & 18 & 20,0 & 72 & 80,0 & \multirow{2}{*}{0,143} \\
\hline$<3$ years & 83 & 28,5 & 208 & 71,5 & \\
\hline \multicolumn{6}{|l|}{ Water source } \\
\hline Local water company & 26 & 32,1 & 55 & 67,9 & \multirow{3}{*}{0,213} \\
\hline Well & 68 & 26,1 & 193 & 73,9 & \\
\hline Others & 8 & 17,8 & 37 & 82,2 & \\
\hline \multicolumn{6}{|l|}{ The existences of a latrine } \\
\hline Yes & 3 & 12,5 & 21 & 87,5 & \multirow{2}{*}{0,176} \\
\hline No & 99 & 27,3 & 264 & 72,7 & \\
\hline \multicolumn{6}{|l|}{ Breakfast habits } \\
\hline Never & 11 & 40,7 & 16 & 59,3 & \multirow{4}{*}{0,11} \\
\hline Rarely & 5 & 13,9 & 31 & 86,1 & \\
\hline Often & 8 & 30,8 & 18 & 69,2 & \\
\hline Always & 78 & 26,2 & 220 & 73,8 & \\
\hline \multicolumn{6}{|l|}{ Nutritional status } \\
\hline Underweight & 26 & 28,6 & 65 & 71,4 & \multirow{4}{*}{0,828} \\
\hline Normal & 66 & 25,9 & 189 & 74,1 & \\
\hline Overweight & 6 & 28,6 & 15 & 71,4 & \\
\hline Obese & 4 & 19,0 & 17 & 81,0 & \\
\hline \multicolumn{6}{|l|}{ History of infectious disease } \\
\hline Yes & 25 & 26,9 & 68 & 73,1 & \multirow{2}{*}{0,989} \\
\hline No & 77 & 26,1 & 218 & 73,9 & \\
\hline \multicolumn{6}{|l|}{ Consumption on animal protein } \\
\hline Less than recommendation & 102 & 26,4 & 284 & 73,6 & \multirow{2}{*}{1} \\
\hline Appropriate to recommendation & 0 & 0,0 & 2 & 100,0 & \\
\hline \multicolumn{6}{|l|}{ Consumtion of plant protein } \\
\hline Less than recommendation & 102 & 26,4 & 285 & 73,6 & \multirow{2}{*}{1} \\
\hline Appropriate to recommendation & 0 & 0,0 & 1 & 100,0 & \\
\hline
\end{tabular}


Tabel A3. Bivariate analysis result

\begin{tabular}{lccccc}
\hline \multicolumn{1}{c}{ Variables } & Anemia & n & Mean & SD & p-value \\
\hline Allowance per day & No & 285 & 11335,09 & 9636,53 & 0,040 \\
& Yes & 102 & 9892,16 & 4116,87 & 0,561 \\
\hline Menstruation period & No & 286 & 6,73 & 1,35 & 1,08 \\
& Yes & 102 & 6,65 & & 0,016 \\
\hline Father's height & & & & 6,73 & 6,89 \\
& No & 279 & 164,39 & 166,29 & \\
\hline Mother's height & Yes & 102 & & 6,20 & 0,584 \\
\hline
\end{tabular}

\section{Copyrights}

Copyright for this article is retained by the author(s), with first publication rights granted to the journal.

This is an open-access article distributed under the terms and conditions of the Creative Commons Attribution license (http://creativecommons.org/licenses/by/4.0/). 